\title{
INCREASING EFL STUDENTS' WRITING SKILL USING JIGSAW AND ONLINE SEARCHING STRATEGY
}

\author{
Yofita Christy Isgiarno*, Bambang Yudi Cahyono, Hasti Rahmaningtyas \\ Universitas Negeri Malang, Indonesia, Indonesia \\ (yofita.christy@gmail.com)
}

Received: $24^{\text {th }}$ April 2020; Revised: $17^{\text {th }}$ May 2020; Accepted: $28^{\text {th }}$ June 2020

\begin{abstract}
Writing is the practice of reaching out to one's mind and exploring it creatively. In writing activity, the writer should have accurate information, strong arguments, and good knowledge of organization and mechanics before delivering their ideas. However, in schools, writing is commonly considered as the most difficult skill to learn by the students of English as a foreign language (EFL). The problems of EFL students' writing could refer to the five aspects of writing: content, organization, language use, vocabulary, and mechanics. This research aimed to increase the quality of the teaching and learning process in the classroom in order to improve EFL students' writing skills by using the Jigsaw and Online Searching Strategy (JOSS). It used Action Research as the research design and was conducted in the tenth grade of Ilmu Bahasa dan Budaya (Language and Culture) class of Public Senior High School (SMA Negeri) 2 in Malang, East Java, Indonesia, which consisted of 22 students. The result showed that all of the students have passed the criteria of success and given good responses to the implementation of JOSS. Therefore, it is suggested that English teachers consider using JOSS as a teaching strategy to improve tenth-grade students' writing skills.
\end{abstract}

Key Words: EFL students; jigsaw; online searching strategy (JOSS); writing skill

\section{ABSTRAK}

Menulis merupakan aktivitas menjangkau pikiran seseorang dan menyampaikannya secara kreatif. Di dalam aktivitas menulis, penulis perlu mempunyai informasi yang akurat, argumen yang kuat, serta pengetahuan yang baik mengenai struktur teks dan mekanik dalam menulis sebelum menyampaikan ide-idenya. Namun, di sekolahsekolah, menulis dipandang sebagai kemampuan yang paling sulit untuk dikuasai oleh para siswa yang mempelajari bahasa Inggris sebagai bahasa asing. Masalah dalam menulis dapat ditemukan dalam lima aspek tulisan yaitu isi, struktur teks, tata bahasa, kosakata, dan mekanik dalam menulis. Penelitian ini bertujuan untuk meningkatkan kualitas dalam proses pengajaran dan pembelajaran dalam kelas untuk meningkatkan kemampuan menulis siswa dalam belajar bahasa Inggris dengan menggunakan jigsaw dan pencarian informasi secara daring. Penelitian ini adalah Penelitian Tindakan. Penelitian ini dilakukan di SMA Negeri 2 Malang, Jawa Timur, Indonesia, pada kelas sepuluh Ilmu Bahasa dan Budaya yang terdiri atas 22 siswa. Hasil penelitian ini menunjukkan bahwa semua siswa telah mencapai kriteria kesuksesan dan memberikan respon yang baik mengenai penerapan strategi jigsaw dan pencarian informasi secara daring. Oleh sebab itu, guru bahasa Inggris disarankan untuk menggunakan strategi tersebut sebagai salah satu upaya untuk meningkatkan kemampuan menulis siswa kelas sepuluh.

Kata Kunci: siswa; jigsaw; pencarian informasi secara daring; kemampuan menulis

How to Cite: Isgiarno, Y. C., Cahyono, B.Y., Rahmaningtyas, H. (2020). Increasing EFL Students' Writing Skill Using Jigsaw and Online Searching Strategy. IJEE (Indonesian Journal of English Education), 7(1), 97-110. doi:10.15408/ijee.v7i1.16383

"Corresponding author

IJEE (Indonesian Journal of English Education), 7 (1), 2020, 95-108

P-ISSN: 2356-1777, E-ISSN: 2443-0390 | DOI: http://doi.org/10.15408/ijee.v7i1.16383

This is an open access article under CC-BY-SA license (https://creativecommons.org/licenses/by-sa/4.0/) 


\section{INTRODUCTION}

Writing is the practice of reaching out to one's mind and exploring it creatively. The writer's process and purpose of writing should be clear. Besides, the writer needs to deliver ideas communicatively and clearly. When writing, a writer usually follows a process of drafting, shaping, rereading, revising, and editing the text. Because of these activities, writing is called as a creative activity. Harmer (2004) described writing as a complex skill. This is because EFL students should have accurate information, strong arguments, and good knowledge of writing organization and mechanics before delivering ideas in their writing.

However, generally, writing is hard for many EFL students. Improving writing skills in the classroom setting is more challenging than other language skills. It has previously been observed that writing is the most challenging skill to learn in the language classroom (Mukminatien, 1997). At school, it has also been noted that students have difficulties in meeting the writing criteria due to language proficiency. Students commonly have inadequate knowledge of English grammar, vocabulary, punctuation, and spelling. This may lead to a lack of interest in writing among students. The result of a study showed that students were frustrated, uninspired, and spent much time before they could start writing exercises (Basuni, 2004). It can be understood that the teaching and learning of writing poses some problems. The problems in writing among EFL students are not only on their low proficiency but also on the strategy in the teaching of writing. According to Ariyanti and Fitriana (2017), EFL students had trouble in using grammar, cohesion, coherence, paragraph organization, diction, and spelling errors in essay writing. Additionally, Hasan and Marzuki (2017) analyzed the EFL students' ability in writing by asking the students to do writing tasks in a determined time. Their findings showed that the grammatical problems covering using plural forms, articles, verb forms, clauses, passive voice, and preposition existed on the students' writing.

One of the methods of teaching is cooperative learning, which is based on the nature of human beings who need to cooperate with other people. Cooperative learning has been found to be successful in increasing not only students' language skill but also their social skills. Moreover, cooperative learning provides student-student full chances of contact with meaningful input and output in a friendly environment (Ahangari \& Samadian, 2014). In cooperative learning group 
work, each member of a group is not only responsible for learning what is taught but also for helping each other in the group to learn and achieve good work. It can be said that students learn when they collaborate cooperatively.

This notion is supported by Slavin (1980), who stated that students get many benefits from exchanging experiences while they function as a collective rather than alone. Similarly, Yusuf, Jusoh, and Yusuf (2019) state that the students got better results in the post-test than in the pre-test of narrative essay writing after the cooperative learning was introduced in the classroom. Not only did the students improve their writing scores, but they also showed good progress in the five writing components. The content, organization, language use, vocabulary, and mechanics are the components of writing an essay (Jacob et al, 1981). Since cooperative learning is also known to provide positive interdependence among students on their group work in enhancing their writing skills, the researchers of the present research were interested in applying one of the cooperative learning techniques, which is a jigsaw.

According to Mengduo and Xiaoling (2010), the jigsaw is an activity which creates interaction by providing students with an opportunity to help each other build comprehension actively. By using jigsaw, students are encouraged to communicate and accomplish the idea of the task given by the teacher, together with their group members actively.

The result of research conducted by Hosseni, Maleki, and Mehrizi (2014) showed that the students were very active in discussing the task together with their jigsaw group, and they also learned in a supportive environment. That is because students played the role of a teacher in the class. Quinn (2006) also stated that by using Jigsaw technique, most students enjoyed working with a partner, and this gave them the motivation to do their work.

Jigsaw also includes a procedure whereby students share information they have gathered with their groupmates and with the mates from other groups in class (Slavin, 1995). The procedures in jigsaw were broken down into several steps.

First, students were divided into several groups called the jigsaw groups or homegroups. Members of each group should identify themselves as Member 1, Member 2, Member 3, and Member 4 (if each group consists of 4 members). In this jigsaw group, they were given a different part of the text. Students who have the same number 
(for example, Member 1) should get the same text (Part 1 of the text).

Second, the students with the same number in the groups or the same part of the text were gathered. This was called the expert group. In their new group, they read and tried to understand the part of the text. They can discuss the content with members of the same group and agree on what the text is about. If there are questions about the part of the text, they can answer them together so that they can fully understand the text.

Third, they go back to the jigsaw group with the information that they had from the expert group. In the jigsaw group, they shared the information that they got to all the group members. In this step, they got complete information about the text through exchanging and sharing information. Through these jigsaw technique activities, students would be able to exchange the ideas within the group. At the end of these activities, they would be able to gather the information and ideas they got from the expert and jigsaw group in the final writing test.

A preliminary study was conducted to find out the problems in writing faced by a class of the tenthgrade students of Public Senior High School 2 at Malang City, East Java,
Indonesia. In the preliminary study, the students were given a writing test, asking them to write a short biography of President Joko Widodo based on a timeline. The result of the test shows that students' writing skill was low as the mean was only 53.8, whereas the minimum passing grade was 75 . The preliminary study also showed that the teacher has never used a jigsaw for teaching writing,

Therefore, in this study, the researchers used jigsaw as the strategy to solve the problem in learning to write a recount text, particularly biography, faced by tenth-grade students of the school. However, unlike in the common jigsaw studies, online searching activity was included and conducted by the students in the expert group (or the second step of the jigsaw and online searching strategy).

Online searching is the activity that is done to gain information through the website using the Internet search engines. According to Bull and Ma (2001), technology and online sources provide and offer unlimited resources to language learners. By using technology, especially the Internet, the students can adjust their learning process by choosing the information they need that their teachers are not able to provide (Gilakjani \& Sabouri, 2017). It means that through 
technology, especially the Internet, students can have broader knowledge than through manual sources. With the inclusion of online searching, the strategy in this study was called Jigsaw and Online Searching Strategy (JOSS).

A recount text, particularly biography, is one of the texts that senior high school students should study. The selection of the text was based on basic competence number 4.5, which was aimed to help students to understand the contextual meaning (4.5.1) and to construct contextual meaning (4.5.2) related to the social function, generic structure, and language features, especially biography, of eminent people either orally or in a written form.

Based on the background, the problem of the research is formulated as follows: How can jigsaw and online searching strategy (JOSS) increase tenth-grade students' writing skills? More particularly, the research aimed to answer three questions: 1) Can JOSS be used to improve the students writing skills?; 2) How is JOSS implemented in the classroom?; 3) Do the students have good responses towards the application of JOSS?

\section{METHOD}

This research was Action Research which was conducted in a classroom setting. Action research which is conducted in a classroom setting is aimed to solve problems faced by a teacher in the classroom (Burns, 1999). From the preliminary study, it was known that the students' problem dealt with how to improve their skill in writing a recount text, particularly biography.

This study was conducted at State Senior High School 2 at Malang, East Java. In this study, the subjects of the research were the students of the tenth grade of Language and Culture study program at the 2019/2020 academic year. There were 32 students in the class. However, 10 students did not join the preliminary study session. In the analysis, only 22 students were involved.

According to Kemmis and McTaggart (1998), action research is represented through spiral cycles. In Action Research, four stages must be conducted in each cycle. The stages are planning the action, implementing the action, observing the action, and reflecting on the observation. The four stages of this study are explained in the following parts.

\section{Planning the Action}

In this stage, the researchers prepared JOSS to improve the tenthgrade students' writing skills. Unlike in the common jigsaw, in JOSS, the 
students are involved in the information searching in the expert group. Then, they return on their jigsaw group after having complete information from online searching and the summary of part of the text. They present and share their part of the text in the jigsaw group order to get the whole story. The last step is that students are asked to write the complete text individually.

The first researcher acted as the teacher who applied JOSS. To run JOSS, she divided the students into eight groups consisting of four students in each group. The general planning of the study consisted of preparing a lesson plan for four meetings, materials, and media of recount text, particularly biography, research instrument (test, questionnaire, and interview guide), and the criteria of success. The implementation was considered to be successful when $80 \%$ or 18 out of 22 students achieved the passing grade, which was 75 in the total score.

\section{Implementing the Action}

In this stage, the teacher implemented the jigsaw and online searching, which had been planned. The researcher divided the writing process into five steps. The description of activities could be seen in Table 1 . The five steps should be done orderly.
Table 1

The Description of Activities

\begin{tabular}{llrlr}
\hline Stage & $\begin{array}{l}\text { Description } \\
\text { Activity }\end{array}$ & of & Core Activity \\
\hline 1. Building & Students & were & - Reading recount \\
knowledge & given & the & text (biography). \\
& example & of & - Identifying the \\
& recount & text & structure r of \\
& (biography) & for & biography text \\
& them to read. & & through doing \\
& & & exercise.
\end{tabular}

$\begin{array}{rlrlr}\text { 2.Grouping } & \text { Students were } & \text { - Contributing } \\ \text { divided } & \text { into } & \text { work in the jigsaw } \\ \text { several groups, } & \text { group. } & \text { Each } \\ \text { and each group } & \text { member of the } \\ \text { consisted of } 4 & \text { group got a } \\ \text { students, called } & \text { different part of } \\ \text { the jigsaw group. the text. } & \end{array}$

\begin{tabular}{llrlr} 
3.Building & \multicolumn{2}{l}{ Students with the } & Filling blank \\
ideas and & same & part & information \\
knowledge & gathered and & through online \\
with the & discussed the & searching and \\
expert & blank information & discuss it together \\
group & using online & with other \\
& searching with members of their \\
& their group expert group.
\end{tabular}

4.Summari Students went zing ideas back to their with jigsaw jigsaw group and group

exchanging

information with each other.

\begin{tabular}{ll} 
5. Writing a & $\begin{array}{l}\text { After having a } \\
\text { complete event, }\end{array}$ (individually). \\
text, & $\begin{array}{l}\text { students were } \\
\text { particularly } \\
\text { asked to write the }\end{array}$ \\
biography complete recount \\
(post-test) & $\begin{array}{l}\text { text, particularly } \\
\text { biography } \\
\text { individually. }\end{array}$ \\
\hline
\end{tabular}




\section{Observing the Action}

According to Latief (2015), an observation is focused on the data related to the criteria of success stated. It means that the researchers had to observe whether or not the implementation of JOSS could affect the students' skill in writing. The instruments to collect data included the test, questionnaire, interview guide, and scoring rubric. The observation of the action was divided into two categories.

The first category was the main data, which were collected from the students' writing test. To see the students' writing score, the researchers used a scoring rubric, including five aspects of writing. They are content. organization, language use, vocabulary, and mechanics. Each aspect had a different proportion of scores. The proportions were content $(30 \%)$, organization $(20 \%)$, language use $(25 \%)$, vocabulary $(20 \%)$, and mechanics $(5 \%)$ (Jacobs et al. 1981) that were relevant to the scoring rubric for recount text particularly biography. Moreover, two raters in this study scored the students' result of writing. They were the English teacher of Senior High School 2 at Malang and one of the researchers of this study. The average scores from two raters were used quantitative data in the analysis.
The second category was the supporting data that were obtained from the result of the questionnaire and interview in order to get qualitative data. The questionnaire was aimed to know the students' opinion about learning to write a recount text, particularly biography, by using JOSS. The questionnaire items required the students to give responses to the use of media and the learning activities. There were eight items with four options: strongly agree, agree, disagree, and strongly disagree. In the administration of the questionnaire, the Indonesian version was used to enable the students to understand the messages fully. The English version of the Questionnaire is included in the Appendix.

For the interview, the researchers used some questions directed to the students. The first question was about the use of JOSS for teaching recount text, particularly biography. The second question was about the media that the teacher used to teach recount text, particularly biography.

\section{Reflecting the Action}

The reflecting stage covered the analysis of the data, which were collected from the observing stage. In this stage, the data from the implementation of the strategy were analyzed quantitatively and qualitatively. The quantitative data 
were obtained through the preliminary writing test and the final writing test. The qualitative data were obtained from the students' questionnaires. The data from the chosen instruments were evaluated to know the students' responses toward the use of media.

The criteria for success were used to determine whether the implementation of JOSS was successful or not.

\section{FINDINGS AND DISCUSSION}

\section{Findings}

\section{Improvement of Students' Writing Skill}

The researchers got the data from students' writing scores in the fourth meeting. The comparison of the students' improvement from the preliminary test and the final test was shown in Figure 1.

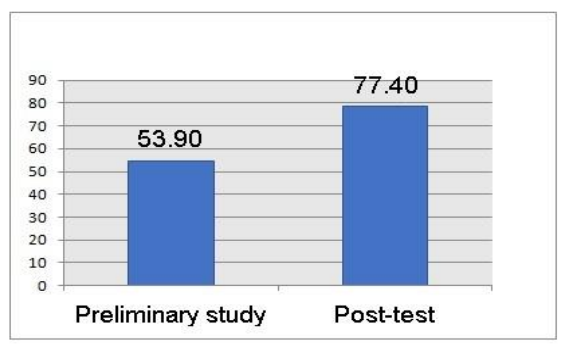

Figure 1. Improvement of the Writing Skill

As shown in Figure 1, the students' writing skills improved when compared to the result of the preliminary study (53.90). The mean of the post-test (77.40) exceeds the minimum passing grade (75).

Additionally, the means the writing components, which are content, organization, language use, vocabulary, and mechanics, also improved (see Table 2).

Table 2. Improvement of the Means of Writing Components

\begin{tabular}{lll}
\hline Components & $\begin{array}{l}\text { Preliminary } \\
\text { study }\end{array}$ & $\begin{array}{l}\text { Post- } \\
\text { test }\end{array}$ \\
\hline Content & 17.5 & 25.9 \\
Organization & 11.2 & 16.9 \\
Language Use & 11.1 & 15.6 \\
Vocabulary & 11.1 & 15.6 \\
Mechanics & 3 & 3.4 \\
\hline Total & 53.80 & 77.40 \\
\hline
\end{tabular}

The improvement of the students' means in each component of the total mean indicated that the students' achievement in writing recount text by using JOSS had met the criteria of success. It was found that there was no significant difference between the students' scores from Rater 1 and Rater 2. The mean from the Rater 1 was 78.50, while the mean from the Rater 2 was 79.40. The mean score that is used by the researchers was the average scores from Raters 1 and 2, which was 77.40. It could be concluded that the students' scores were reliable, and this research was successful. Therefore, the researchers did not need to continue to Cycle 2. 


\section{The Implementation of JOSS}

In this study, the learning process using a cooperative learning approach, the jigsaw technique, and online searching as the media was divided into five steps. There were four meetings in one cycle to implement the steps.

The first step was building knowledge. This step was done in the first meeting. The students were helped by the teacher to understand the social function, generic structure, and language features of recount text, particularly biography. To help students for better understanding, they were given an example of a biography and did an exercise with their chair mates.

The second step was grouping, which was in the second meeting. In this step, the students were divided into 8 jigsaw groups, each of which consisted of 4 students. In the jigsaw group, each member of the group was given one specific part of the text, which contained blank information. Everyone in the group had different parts, namely orientation (Member 1), event 1 (Member 2), event 2 (Member $3)$, and reorientation (Member 4). Students were told to pay attention to their written part and guessed what sequence or event might happen related to the part with blank information that they got.

The third step was building ideas and knowledge within the expert group. This step was also done in the second meeting. Students with the same part were gathered and discussed the blank information with members of their expert group. In their expert group, students tried to find information through online searching to fill the blank information according to the part of the organization of the text. They built their ideas and summarized the events according to the information that they got through online searching.

The fourth step was summarizing ideas with the jigsaw group. This step was done in the third meeting. In this step, students went back to their jigsaw group after having complete information or a summary of one part of the text. They presented and shared the part of the text in their jigsaw group in order to get the whole story. The students also made summaries of the discussion that they did with the members of the jigsaw group.

The fifth step was doing the writing post-test. This step was done in the fourth meeting, which was the last meeting. Students were asked to write a complete recount text individually from the information that they had already got in the expert and the jigsaw group 
discussion. The five steps were done in four meetings orderly.

\section{Students' Responses to the Implementation of JOSS}

Twenty two students were involved in the steps of jigsaw and online searching strategy completely. In the last meeting, the researchers distributed the questionnaire after they had finished working on the post-test.

The analysis of responses showed that all the students (100\%) liked learning English by using JOSS (Item 1), agreed that using JOSS made them easier to understand the material of writing recount text, particularly biography (Item 2), and agreed that JOSS helped them increase their writing skill (Item 3). It was proven by the average of the students' scores from the preliminary study and from the final writing test, which showed some improvement. It means that the students can understand the material of recount text better using JOSS.

When asked about whether they had difficulties in writing (Item 4), 20 students $(90 \%)$ stated that they did not have any difficulties when they learned in their jigsaw group. However, 2 students $(10 \%)$ stated that they had difficulties when they learned in their jigsaw group. These two students were confused about receiving information from the members of the jigsaw group because their explanation was not clear enough.

All of the students (100\%) agreed that using JOSS helped them arrange the words in order to make sentences in the text (Item 5), agreed that using JOSS made writing easier because they could learn from each other in the jigsaw group (Item 6), agreed that JOSS was interesting (Item 7), and agreed that JOSS could support the process of learning to write (Item 8). It was also proven by the jigsaw activities that have been done by the students. They were active in exchanging ideas and information related to the topic that was given by the researchers.

From the interview, it was revealed that most students gave positive responses to the use of JOSS. They said that in the jigsaw group, they could help each other and learned from group members conveniently. Therefore, the implementation of JOSS helped them to write recount text, particularly biography better.

\section{Discussion}

\section{The Improvement of the Students' Skill in Writing}

Based on the result of the study, the students improved their skill in writing recount text, particularly biography, following the application of JOSS. All of the students $(100 \%)$ reached the criteria 
of success. In addition, the use of JOSS improved the five components of writing: content, organization, language use, vocabulary, and mechanics. The students could develop their ideas into paragraphs well from the result of exchanging ideas from the expert group to the jigsaw group. This is in line with the finding of Mengduo and Xiaoling (2010), who stated that the students could have the opportunity to help each other for better comprehension by discussing actively through jigsaw activity. By using jigsaw, students could communicate and accomplish the task with their group members actively. Therefore, they could organize content orderly. Most of the students completed the generic structure of the recount text, which were orientation, events, and reorientation.

Another writing component reinforced was language use and vocabulary. The students' average score in language use and vocabulary improved. Through group discussion and online searching, the students could write using good language and good diction. It is also in line with Gilakjani and Sabouri (2017). They stated that by using technology and the Internet, students could adjust their learning process by choosing the information they need when their teacher cannot provide it completely.
The students' average score on mechanics was also elevated from 3 to 3.4. They made fewer errors in spelling, punctuation, capitalization, and paragraphing. It is also in line with the finding of Yusuf, Jusoh, and Yusuf (2019), who stated that in their study, the students' post-test scores were better than their pre-test scores by using cooperative learning (jigsaw technique).

\section{The Implementation of JOSS}

In this study, the researchers used JOSS in four meetings with five steps of learning. The learning was done as planned. The students gave a positive attitude while they were learning and discussing in their jigsaw group. They were also enthusiastic in paying attention to the teacher's explanation of their jigsaw and expert groups. Some students also tried to help their group members who did not understand the topic very well. They were active in discussing and searching the information through online searching on their jigsaw and expert groups, respectively. This is in line with the finding by Hosseni et al (2014). They stated that the students were very active and enthusiastic in sharing experiences and discussing materials within their jigsaw group to accomplish group work together.

The use of jigsaw and online searching strategy made students more 
active in a writing activity. Moreover, they could cooperate in a group and work actively. It is in line with Ahangari and Samadian (2014), who stated that by using cooperative learning, students not only can improve their language skills but also social skills because they have chances to interact with other students actively. In cooperative learning, each student within the group should help each member of the group to learn and complete the task in order to create a good teamwork achievement. Therefore, it can be said that students learn effectively when they work cooperatively.

In addition, the researchers divided the writing process into five workable steps: (1) building students' knowledge about social function, generic structure, and language features of recount text, particularly biography; (2) grouping the students into a Jigsaw group, (3) asking the students to develop ideas in the expert group about the specific part of their text through online searching, (4) asking the students to summarize ideas in the jigsaw group so that they could exchange information that they brought from the expert group in order to build complete recount text, particularly biography, and (5) asking the students to do a test of writing a recount text, particularly biography.

\section{The Students' Responses toward the Implementation of JOSS}

From the result of the students' response in the questionnaire it showed that most of the students considered that JOSS was good to help them organize their ideas for writing. Moreover, they were happy to be able to share their ideas with their jigsaw group. It is in line with Mengduo and Xiaoling (2010), who stated that jigsaw is an activity that creates interaction by providing students with an opportunity to help each other build comprehension actively.

In addition, by using the jigsaw, students can be motivated to communicate and accomplish the idea of the task that will be given by the teacher, together with their group members actively. It is also in line with Aranson (1978), who stated that the advantage of the jigsaw technique is that students interact with others in getting full information, and it increases their social skills in communicating and delivering their ideas to other members of the group.

\section{CONCLUSION AND SUGGESTION}

Based on the result of this study, it can be concluded that the application of JOSS improved students' skills in writing recount text, particularly biography. The students were 
successful in generating and developing ideas, selecting more appropriate tense and vocabulary, and using correct spelling and punctuation. The result of this study has reached the criteria for success. This was proven by the fact that $100 \%$ of the students passed the minimum passing grade (Kriteria Ketuntasan Minimal/KKM). Furthermore, the majority of the students gave positive responses to the implementation of JOSS.

The results of this research provide some benefits and give some information to the English teachers about the use of JOSS in EFL students' writing skills. Accordingly, it is recommended that English teachers consider using JOSS in order to improve the teaching-learning process, especially for recount text. For future researchers, the result of this study can be used as a reference to conduct research about improving students' skills in writing. Future researchers can also examine the use of JOSS for other skills such as listening, speaking, or reading.

\section{REFERENCES}

Ahangari, S., \& Samadian, Z. (2014). The effect of cooperative learning activities on the writing skills of Iranian EFL learners. Linguistics and Literature Studies, 2(4), 121-130.
Aranson, E. (1978). Implementing jigsaw in the language classroom. In C. Kessler (Ed)., Cooperative language learner: A teacher resource book. New Jersey: Practice Hall.

Ariyanti, A., \& Fitriana, R. (2017). EFL students' difficulties and needs in essay writing. Advances in Social Science, Education and Humanities Research (ASSEHR), 158, 111-121.

Basuni. (2004). Using questioning technique to improve the ability of the second year students of SLTP Negeri 1 Haruai in writing paragraph (Unpublished Master Thesis). Malang: Universitas Negeri Malang.

Baron, R. (2019). Employing jigsaw in English academic writing: An action research in an EFL class in Indonesia. Research and Innovation in Language Learning, 2(3), 233-234.

Bull, S., \& Ma, Y. (2001). Raising learner awareness of language learning strategies in situations of limited recourses. Interactive Learning Environments, 9(2), 171-200.

Burns, A. (1999). Collaborative action research for English language teachers. Cambridge: Cambridge University Press.

Gilakjani, A. P., \& Sabouri, N. B. (2014). Role of Iranian EFL teachers about using pronunciation power software in the instruction of English pronunciation. English Language Teaching, 7(1), 139-148.

Harmer, J. (2004). How to teach writing. Essex: Pearson Education. 
Hasan, J., \& Marzuki, M. (2017). An analysis of student's ability in writing at Riau University Pekanbaru. Theory and Practice in Language Studies, 7(5), 380388.

Hosseni, S. M., Maleki, R., \& Mehrizi, A. A. H. (2014). On the impact of using jigsaw II technique on the development of writing performance of Iranian intermediate EFL learners. International Journal of Language Learning and Applied Linguistics World, 11(4), 198-215.

Jacobs, H. L., Zingraf, S. A., Wormuth, D.R. Hartfiel, V. F., \& Hughey, J. B. (1981). Teaching ESL composition: A practical approach. London: Newbury House Publishers.

Kemmis, S., \& McTaggart, R. (1998). The action research planner (3rd ed.). Deakin University, Australia: Deakin University Press.

Latief, M. A. (2015). Research method on language learning: An introduction. Malang: State University of Malang Press.

Mengduo, Q., \& Xiaoling, J. (2010). Jigsaw strategy as a cooperative learning technique: Focusing on the language learners. Chinese Journal of Applied Linguistics, 33(4), 113-125.

Mukminatien, N. (1997). The difference of students' writing achievement across different courses levels (Unpublished Dissertation). Malang: Universitas Negeri Malang.

Quinn, P. (2006). Cooperative learning and student motivation. Education and Human Development Master's Theses, The College at Brockport. State University of New York.

Slavin, R. E. (1980). Cooperative learning. Review of Educational Research. Boston: Allyn \& Bacon. Retrieved from https://journals.sagepub.com/doi/a bs/10.3102/00346543050002315

Slavin, R. E. (1995). Cooperative learning: Theory, research and practice ( $2^{\text {nd }}$ ed.). Boston: Allyn \& Bacon.

Yusuf, Q., Jusoh, Z., \&Yusuf, Y. (2019). Cooperative learning strategy to enhance writing skills among second language learners. International Journal and Instruction, 12(1), 20-32. 


\section{APPENDIX: The Questionnaire}

Instruction. Respond to the questionnaire by ticking $(\mathrm{V})$ one of the available options:
SA: Strongly Agree
A: $\quad$ Agree
D: $\quad$ Disagree
SD: Strongly Disagree

\begin{tabular}{|c|c|c|c|c|c|}
\hline No & Item & SA & $\mathbf{A}$ & D & SD \\
\hline 1 & $\begin{array}{l}\text { I like to learn English by using cooperative learning, } \\
\text { especially Jigsaw and Online Searching Strategy. }\end{array}$ & & & & \\
\hline 2 & $\begin{array}{l}\text { The use of the Jigsaw and Online Searching Strategy } \\
\text { made me easier to understand the material of writing } \\
\text { recount text, particularly biography. }\end{array}$ & & & & \\
\hline 3 & $\begin{array}{l}\text { The use of Jigsaw and Online Searching Strategy } \\
\text { helped me increase my writing skill. }\end{array}$ & & & & \\
\hline 4 & $\begin{array}{l}\text { I have difficulties in writing in cooperative learning } \\
\text { when the teacher used Jigsaw and Online Searching } \\
\text { Strategy }\end{array}$ & & & & \\
\hline 5 & $\begin{array}{l}\text { The use of cooperative learning with Jigsaw and } \\
\text { Online Searching Strategy helped me arrange the } \\
\text { words in order to make sentences in the recount text } \\
\text { because I was helped by other group members, }\end{array}$ & & & & \\
\hline 6 & $\begin{array}{l}\text { The use of Jigsaw and Online Searching Strategy } \\
\text { made writing easier because I could learn from each } \\
\text { other in the jigsaw group }\end{array}$ & & & & \\
\hline 7 & $\begin{array}{l}\text { In my opinion, it is interesting to use Jigsaw and } \\
\text { Online Searching Strategy. }\end{array}$ & & & & \\
\hline 8 & $\begin{array}{l}\text { In my opinion, the use of Jigsaw and Online } \\
\text { Searching Strategy supported me in the process of } \\
\text { learning to write in the classroom. }\end{array}$ & & & & \\
\hline
\end{tabular}

